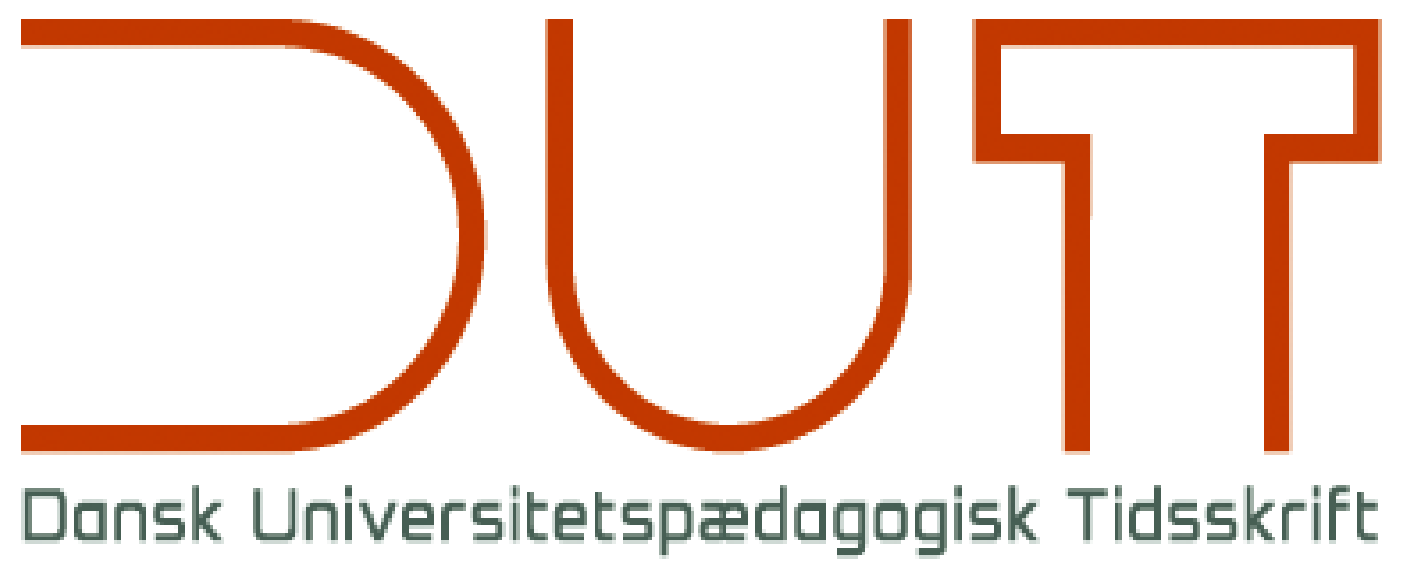

Tema

Ledelse, udvikling og overlevelse på universitetet

Årgang 12 nr. 22 / 2017

Titel

Informationskompetente studieledere - om sammenhænge mellem studielederes brug af videnskilder og deres ledelsestilgange

Forfatter

Sidetal

Thomas Harboe, Camilla Østerberg Rump, Jette Hyldegård og Jesper Bruun

$48-63$

Udgivet af

Dansk Universitetspædagogisk Netværk, DUN

URL

> http://dun-net.dk/

Betingelser for brug af denne artikel

Denne artikel er omfattet af ophavsretsloven, og der må citeres fra den. Følgende betingelser skal dog være opfyldt:

- Citatet skal være i overensstemmelse med "god skik“

- Der må kun citeres „i det omfang, som betinges af formålet"

- Ophavsmanden til teksten skal krediteres, og kilden skal angives ift. ovenstående bibliografiske oplysninger.

(c) Copyright

DUT og artiklens forfatter 


\section{Informationskompetente studieledere - om sammenhænge mellem studielederes brug af videnskilder og deres ledelsestilgange}

Thomas Harboe, centerleder, ph.d., Pædagogisk Center Samfundsvidenskab, Københavns Universitet

Camilla Østerberg Rump, lektor, ph.d., Institut for Naturfagenes Didaktik, Københavns Universitet

Jette Hyldegård, studieleder, ph.d., Det Informationsvidenskabelige Akademi, Københavns Universitet

Jesper Bruun, adjunkt, ph.d., Institut for Naturfagenes Didaktik, Københavns Universitet

\section{Reviewet artikel}

Studieledelse er under pres fra styringstiltag, der kræver at studieledere i dag kan balancere kompetent mellem pædagogisk og administrativ ledelse. Artiklen ser nærmere på mulige træk ved denne udvikling igennem en undersøgelse af studielederes brug af viden og syn på studieledelse. På baggrund af en spørgeskemaundersøgelse blandt studieledere på et større dansk universitet identificeres en mulig sammenhæng mellem studielederes brug af videnskilder og deres opfattelser af studieledelse. Analysens implikationer for praksis diskuteres, herunder for udvikling af studier og undervisning lokalt. Det konkluderes, at der er behov for at følge op på undersøgelsens resultater med en større undersøgelse.

\section{Introduktion}

Studieledelse er i dag under pres fra styringstiltag og New Public Management (NPM) med øget fokus på udvikling samt performancekontrol og -måling. Udviklingen kræver studieledere, der til stadighed kan balancere kompetent mellem pædagogisk og administrativ ledelse samt mellem det personlige, det lokale og det organisatoriske niveau på universitetet.

Dette billede bekræftes til fulde af faglitteraturen, både nationalt og internationalt (Christiansen, Harboe, Horst, Krogh. \& Sarauw, 2013; Graversen, 2009; Harboe, 2013; 2015; Kallenberg, 2015; 2016; Kristensen, 2011; Mårtensson \& Roxå, 2016; Mårtensson, Roxå, \& Stensaker, 2014; Mårtensson, Roxå \& Stensaker, 2015; Nørreklit \& Raffnsøe-Møller, 2011; Wright \& Ørberg, 2008). Kallenberg (2015) beskriver fx, hvordan arbejdsbetingelserne for studieledere gennem de seneste 25 år har ændret sig gradvist og dog samtidig ret dramatisk. Indtil 1990'erne blev studielederne opfattet som erfarne undervisere eller professorer, der så også samtidig var engageret i forefaldende administrativt arbejde. Siden årtusindskiftet er der sket et markant skift i fokus. Med 
NPM's indtog er der i dag fokus på virksomhedsstrategier, budgetter, studerendes gennemførsel, frafald og fastholdelse samt en generel opmærksomhed på effektivitet. Resultatet er, at forventningsniveauet til studieledernes viden, færdigheder og kompetencer er stærkt stigende, herunder ikke mindst inden for det, som vi i denne artikel vil betegne som den informationskompetente studieleder. At være en informationskompetent studieleder kræver, at man ikke alene kender den organisation og faglighed, man indgår i, men også at man har et dybdegående kendskab til pædagogik og ledelse samt ved, hvor og hvordan man kan opsøge og bruge relevant materiale, fagog forskningslitteratur. Hvad der er relevant information og viden afhænger som regel af den konkrete situation, problemstilling og opgave, men valg af kilde har betydning for opgaveløsningen. I den ene ende har vi 'anekdotisk viden', som man som studieleder opnår ved tale med lokalmiljøet og 'lytte på vandrørene'. I den anden ende har vi den systematisk indsamlede viden i form af 'nøgletal' eller mere forskningsbaseret viden om uddannelse og undervisning. Hver situation og opgave kræver et reflekteret valg af kilder, men også her er der i dag et pres udefra og en forventning om, at studieledere i højere grad systematisk indhenter og anvender information samt i stigende grad, selv bidrager med samme, fx i form af nøgletal.

Det er et åbent spørgsmål, hvorvidt studielederne i dag mestrer denne komplekse opgave: at være informationskompetente ledere. To nylige rapporter peger på, at dette ikke er tilfældet, og at det især halter med hensyn til det mere systematiske og standardiserede ledelsesgrundlag (Kvalitetsudvalget 2015; Rigsrevisionen, 2008).

Rigsrevisionens rapport fra 2008, der omfatter $90 \%$ af universiteternes studieledere på bachelor- og kandidatuddannelserne i 2007, tegner et billede af en ad hoc-præget studieledelse uden helhedsorientering og uden systematisk brug af de udviklingsredskaber, der faktisk findes. Det fremgår bl.a., at undervisningsevalueringer er tynget af meget lave svarprocenter, og de bliver ofte kun set og brugt af studienævnene. Studielederens og de enkelte underviseres opfølgning på studenterevalueringerne er mere sporadisk. Faktisk rapporterer en stor del af de adspurgte studieledere i Rigsrevisionens undersøgelse, at de ikke har systematisk kontakt med deres undervisere, og dermed heller ikke systematisk følger op på de studerendes evalueringer. Det er kun $60 \%$ af de 200 medvirkende studieledere i undersøgelsen, der har et halvårligt eller årligt møde med de interne undervisere, og kun $45 \%$ har tilsvarende kontakt med de eksterne undervisere. Rapportens resultater får Rigsrevisionen til at efterlyse en mere helhedsorienteret og systematisk tilgang til både viden og ledelse ved universiteterne. Desuden anbefaler rapporten, at 'samle' ledelsesansvaret for bedre at kunne lede kvalitetssikringen af uddannelserne.

Syv år senere i 2015 finder man tilsvarende analyser i rapporten fra det ministerielle Udvalg for Kvalitet og Relevans i de Videregående Uddannelser (herefter Kvalitetsud- 
valget). Blandt de mange anbefalinger til bedre kvalitet og relevans i uddannelsessystemet var der også anbefalinger, der direkte adresser studielederne ved landets universiteter. Der er, ifølge Kvalitetsudvalget, behov for en langt mere systematisk og konsistent indsamling af ledelsesinformation på tværs af uddannelser og institutioner, hvis institutions- og studieledelser, studerende, ministerier og politikere skal kunne arbejde målrettet med uddannelsernes kvalitet og relevans. Det indebærer bl.a. flere standardiserede kvantitative opgørelser af generel og systematisk karakter. Ifølge Kvalitetsudvalget bør studielederne desuden tilføres et mere formelt beslutningsmandat.

Med dette udgangspunkt er vi interesseret i at studere træk ved studieledernes informationsbrug og informationskompetence i dag, her forstået som '... an awareness of how they gather, use, manage, synthesise and create information and data in an ethical manner and will have the information skills to do so effectively' (SCONUL, 2011, s. 3).

Konkret ønsker vi at belyse følgende to spørgsmål:

1. Hvilke kilder bruger studieledere til at tilvejebringe viden om pædagogiske forhold (bredt forstået)?

2. Kan vi spore sammenhænge mellem, hvordan studieledere bruger videnskilder om pædagogiske forhold og deres ledelsestilgange - og på den måde generere hypoteser om, hvordan studieledere navigerer ledelsesmæssigt?

Hvor det første spørgsmål er umiddelbart klart og deskriptivt, er det andet spørgsmål af en mere eksplorativ karakter, som vi ikke forventer entydige svar på. Vi er her især ude efter mulige hypoteser om hvordan studieledelse forventeligt påvirkes og ændres som konsekvens af kravet om et mere systematisk og standardiseret ledelsesgrundlag.

\section{Metode}

Artiklen er baseret på en spørgeskemaundersøgelse blandt studieledere på Københavns Universitet (herefter KU) samt studier af relevant faglitteratur. Især har Harboes (2013) ph.d.-afhandling om studieledelse influeret formuleringerne af spørgsmålene. Spørgeskemaundersøgelsen blev gennemført i efteråret 2015. Spørgeskemaet bestod af 37 udsagn/variabler om studieledelse. 19 spørgsmål omhandlede studieledernes opfattelse af deres organisatoriske forhold (Likert skala, 1-5), mens 18 spørgsmål omhandlede deres nuværende og fremtidige brug af kilder til viden (skala 0-4). Dertil kom en 'ved ikke/ikke relevant'-kategori. I tillæg var der ni baggrundsspørgsmål.

Spørgeskemaet blev distribueret til i alt 86 respondenter på tværs af de seks fakulteter på KU. I alt 66 respondenter (alle fakulteter repræsenteret) besvarede skemaet, hvilket 
svarer til en svarprocent på 77 \%. Respondenterne er alle involveret i studieledelse ved $\mathrm{KU}$, som dog er kendetegnet ved at være heterogent organiseret på tværs af fakulteter (se tabel 1). Skønt flertallet af respondenter har titlen 'studieleder', er der også et antal studienævnsformænd, uddannelsesrådsformænd og viceinstitutledere for undervisning blandt respondenterne. Fælles for dem gælder, at de er involveret i studieledelse i en eller anden form, og at de er uformelle ledere i den forstand, at de er uden direkte ledelsesansvar for (fastansat) personale og kun i begrænset omfang ansvarlig for økonomi. De er dog ikke mere uformelle, end at de alle også spiller en særdeles central ledelsesrolle i universiteternes daglige drift og udvikling.

\begin{tabular}{|c|c|c|c|c|c|c|}
\hline \multicolumn{2}{|l|}{$N=66$} & $\begin{array}{l}\mathrm{SCl}- \\
\mathrm{ENCE}\end{array}$ & SUND & $\begin{array}{l}\text { SAMF/ } \\
\text { JUR }\end{array}$ & $\begin{array}{l}\text { HUM/ } \\
\text { TEO }\end{array}$ & I alt \\
\hline \multirow{2}{*}{$\begin{array}{l}\text { Erfaring som } \\
\text { studieleder }\end{array}$} & \multirow{2}{*}{$\begin{array}{l}<4 \text { år } \\
>4 \text { år }\end{array}$} & 13 & 11 & 3 & 6 & 33 \\
\hline & & 12 & 11 & 4 & 6 & 33 \\
\hline \multirow{2}{*}{$\begin{array}{l}\text { Normeret arb.- } \\
\text { tid } \\
\text { til studieledelse }\end{array}$} & \multirow{2}{*}{$\begin{array}{l}<50 \% \\
>50 \%\end{array}$} & 20 & 16 & 2 & 4 & 42 \\
\hline & & 2 & 1 & 4 & 8 & 15 \\
\hline \multirow{2}{*}{\multicolumn{2}{|c|}{$\begin{array}{ll}\text { Studieleder for } & 1-3 \text { uddannel- } \\
& \text { ser } \\
\text { antal uddannel- } & 4+\text { uddannel- } \\
\text { ser } & \text { ser }\end{array}$}} & 24 & 20 & 6 & 1 & 51 \\
\hline & & 1 & 2 & 1 & 11 & 15 \\
\hline \multirow{2}{*}{$\begin{array}{l}\text { Studieleder for } \\
\text { antal studerende }\end{array}$} & \multirow{2}{*}{$\begin{array}{l}<500 \text { stu- } \\
\text { denter } \\
>\quad 500 \text { stu- } \\
\text { denter }\end{array}$} & 19 & 17 & 2 & 0 & 38 \\
\hline & & 6 & 5 & 5 & 12 & 28 \\
\hline \multicolumn{2}{|c|}{ Medlem af instituttets ledelse } & 3 & 2 & 5 & 9 & 19 \\
\hline \multicolumn{2}{|c|}{ Medlem af studienævn } & 5 & 18 & 7 & 7 & 37 \\
\hline \multicolumn{2}{|c|}{$\begin{array}{l}\text { Deltagelse i ledelsesudviklingsfor- } \\
\text { løb (LUKU) }\end{array}$} & 16 & 13 & 6 & 8 & 45 \\
\hline \multicolumn{2}{|c|}{$\begin{array}{l}\text { Deltaget i KU's studielederforum } \\
\text { eller lignende netværk }\end{array}$} & 18 & 20 & 4 & 11 & 53 \\
\hline \multicolumn{2}{|l|}{ Respondenter ialt } & 25 & 22 & 7 & 12 & 66 \\
\hline
\end{tabular}

Tabel 1. Signalement af studieledelse på KU baseret på 9 baggrundsspørgsmål

I tilknytning til den statistiske efterbehandling af data er der dels brugt ANOVA (ANalysis Of VAriance) og en efterfølgende Tukey-analyse til at identificere forskelle i studielederes brug af viden, dels er der foretaget en faktoranalyse for at spore sammenhænge i materialet. En 'faktor' kan ses som en underliggende dimension af de data, vi har indsamlet. Hvis folk fx ofte svarer ens i en undersøgelse på spørgsmål om indkomst, uddannelse og beskæftigelse, så udgør det til sammen den latente underliggende dimension socioøkonomisk status. Faktoranalysen viser med andre ord distinkte 'klumper' af svar i vores datamateriale, hvor respondenterne har svaret ens. 
Hver respondent kan vel at mærke godt score højt på flere faktorer, og derfor er der ikke tale om en inddeling af respondenterne i typer, men snarere i forskellige tilgange, som deltagerne kan bruge afhængig af konteksten.

\section{Teoretisk ramme}

Til brug for design af spørgeskema samt den efterfølgende dataanalyse har vi udviklet en teoretisk ramme (figur 1), hvorunder vi har indplaceret de undersøgte videnskilder alt efter deres karakteristika i henhold til to akser: Ad hoc $\leftrightarrow$ Systematisk hhv. Erfaringsbaseret $\leftrightarrow$ Forskningsbaseret. Hermed får vi tre kombinationspar:

ad hoc - erfaringsbaseret (anekdotisk), erfaringsbaseret - systematisk (administrativ) samt systematisk - forskningsbaseret (forskning). Kombinationsparret forskningsbaseret-ad hoc er ikke anvendt, da vi betragter den som ikke eksisterende.

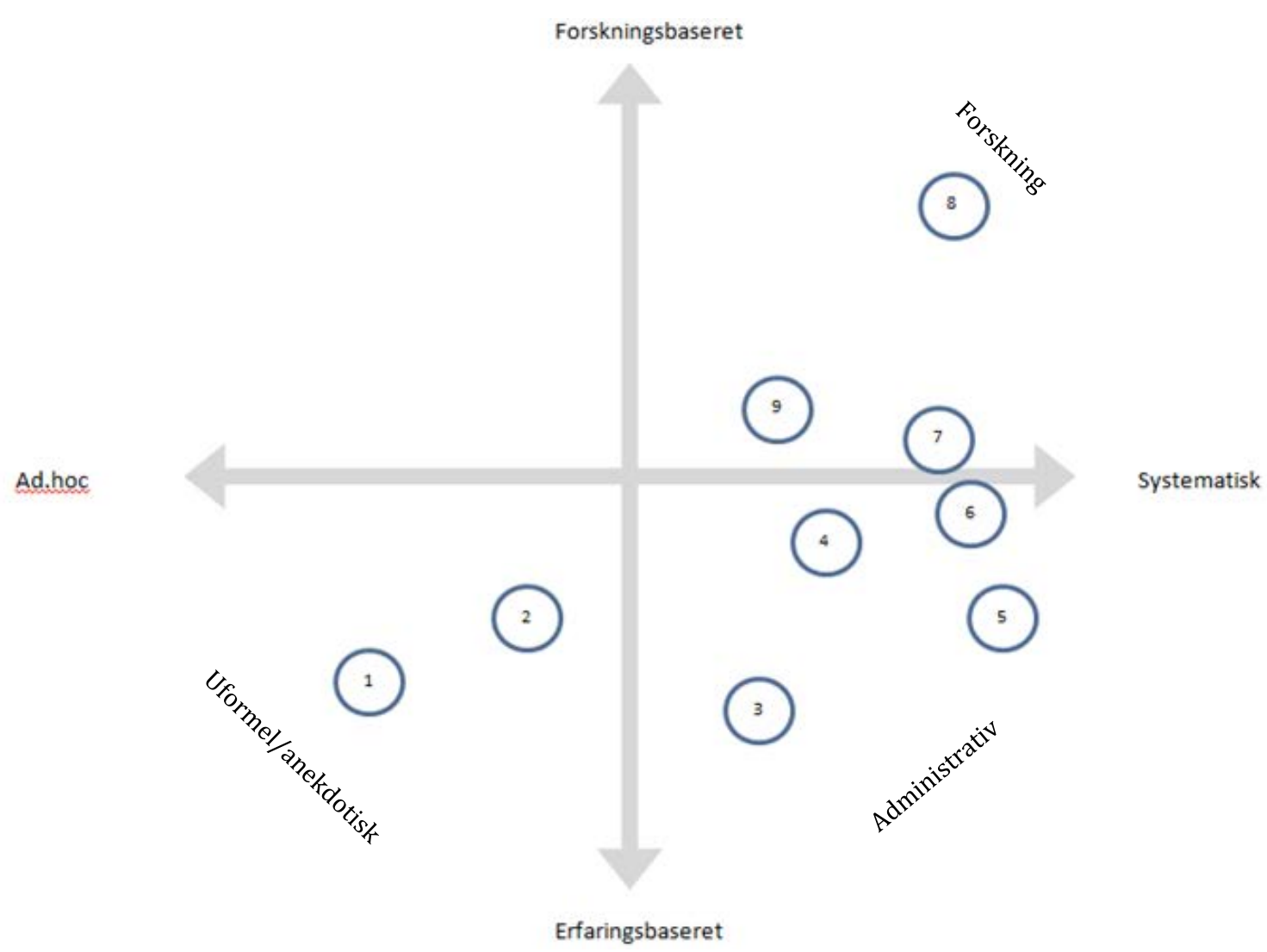

Figur 1. Ni videnskilder fordelt på to dimensioner 
I figur 1 er de ni videnskilder, som vi eksaminerer i spørgeskemaet, placeret i den teoretiske ramme. De ni videnskilder er:

\begin{tabular}{|c|c|c|}
\hline $\begin{array}{l}\text { Erfaringsbaseret - ad hoc } \\
\text { Uformel/anekdotisk }\end{array}$ & $\begin{array}{l}\text { Erfaringsbaseret - systema- } \\
\text { tisk } \\
\text { Administrativ }\end{array}$ & $\begin{array}{l}\text { Forskningsbaseret - syste- } \\
\text { matisk } \\
\text { Forskning }\end{array}$ \\
\hline $\begin{array}{l}\text { 1. Tæt kontakt til undervi- } \\
\text { serne } \\
\text { 2. Tæt kontakt til stude- } \\
\text { rende }\end{array}$ & $\begin{array}{l}\text { 3. Undervisningsevaluerin- } \\
\text { ger } \\
\text { 4. Uddannelsesevaluerin- } \\
\text { ger, akkrediteringer, o. } \\
\text { lign. } \\
\text { 5. Studiestatistikker, stu- } \\
\text { dieadministrative noter } \\
\text { o. lign. } \\
\text { 6. Ministerielle rapporter, } \\
\text { høringer o.lign. }\end{array}$ & $\begin{array}{l}\text { 7. Eksterne konsulentrap- } \\
\text { porter } \\
\text { 8. Universitetspædagogisk } \\
\text { forskning } \\
\text { 9. Universitetspædagogi- } \\
\text { ske kurser, konferencer, } \\
\text { og lign }\end{array}$ \\
\hline
\end{tabular}

Den præcise placering af videnskilderne bygger på vores kvalificerede skøn og kan altså diskuteres. Man skal dog være opmærksom på, at den eksakte afstand mellem kilderne ikke er afgørende, og at vi taler om et vist fællestræk mellem videnskilderne snarere end om de enkelte kilder. Vi opererer således med en antagelse om, at kilderne 1 og 2 har et fællestræk ved at være uformelle og anekdotiske, at kilderne 3, 4, 5 og 6 har et fællestræk ved at være administrative og at kilderne 7, 8 og 9 har et fællespræg ved at være forskning eller i det mindste forskningsbaserede.

\section{Resultater}

I det følgende afsnit gennemgås resultatet af spørgeskemaundersøgelsen.

Resultat 1: Ifølge studielederne selv er ad hoc-kilder til viden om pædagogiske forhold (bredt forstået) signifikant mest anvendt

Figur 2 viser, hvordan de adspurgte studieledere, ifølge dem selv, bruger forskellige kilder til viden om pædagogiske forhold. Det overordnede spørgsmål var: 'I hvor høj grad bygger din nuværende viden om pædagogiske forhold på følgende kilder?'. Tallene 1-9 i den hvide cirkel henviser til typen af videnskilde, jf. figur 1 ovenfor, og tallene i den mørke ellipsecirkel viser den gennemsnitlige score i intervallet 0-4, hvor 4 udtrykker 'i meget høj grad' og 0 udtrykker 'slet ikke'.

ANOVA viser, at studielederne bruger uformelle og anekdotiske videnskilder i signifikant højere grad $(p<0,05)$, end de bruger administrative eller forskningsbaserede kilder til viden. Vores umiddelbare tolkning af dette resultat er, at det isoleret set er en 
bekræftelse af det manglende systematiske ledelsesgrundlag, som både Rigsrevisionen (2008) og Kvalitetsudvalget (2015) fandt og kritiserede ved danske universiteter.

Desuden er det påfaldende, at studiestatistikker, studieadministrative sagsnotater, ministerielle rapporter, akkrediteringer m.m. scorer så lavt set i lyset af, hvor meget der i dag tales om New Public Management i den offentlige sektor generelt.

Selve det at studielederne ifølge dem selv bruger situerede og uformelle videnskilder, kan dog skyldes (mindst) tre forhold: (1) At studielederne har en præference for denne type viden, (2) at studielederne har let adgang til tæt dialog med studerende og undervisere, og/eller (3) at de får mange administrative data, men at de ikke mener det siger særligt meget om pædagogiske forhold.

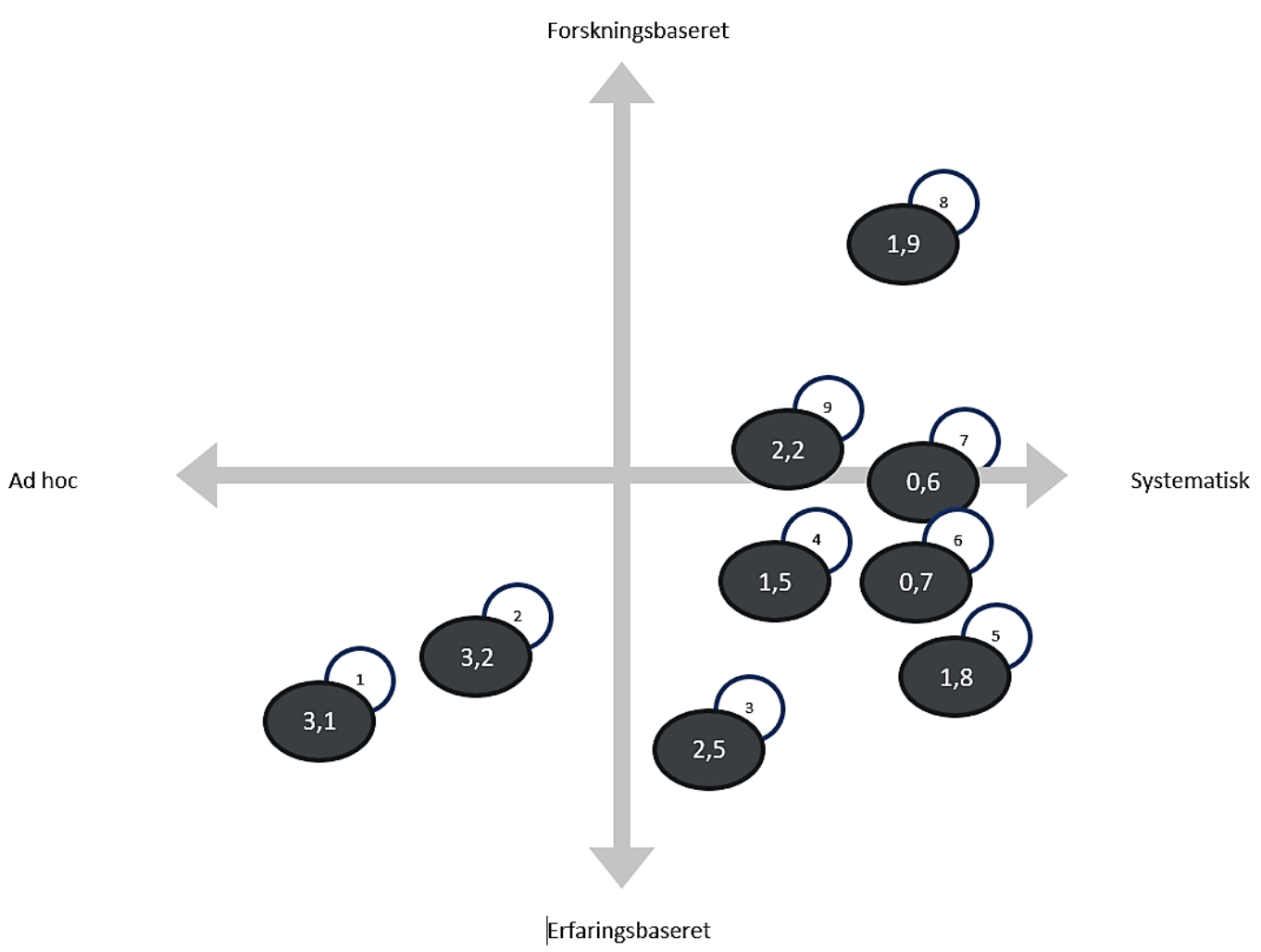

Figur 2. Brug af kilder til viden om pædagogiske forhold

Resultat 2: Der kan spores en sammenhæeng mellem studieledernes brug af videnskilder og deres opfattelse af studieledelse og organisatorisk adfærd

Spørgsmål 2 i vores problemformulering om, hvorvidt vi kan spore sammenhænge mellem, hvordan studieledere ifølge dem selv tilgår viden om pædagogiske forhold og deres ledelsestilgange er som nævnt af mere eksplorativ og hypotesegenererende karakter. Vi har i denne forbindelse benyttet os af en faktoranalyse og herigennem identificeret fem faktorer, hvoraf de tre i høj grad er kendetegnet ved brug af videnskilder. 
De sidste to faktorer er karakteriseret ved andre organisatoriske vilkår og behandles andetsteds (Harboe et al., 2016).

Figur 3 præsenterer studieledernes brug af videnskilder i relation til de tre tilgange, som faktoranalyserne har udpeget. Det første, der er værd at bemærke, er, at de tre faktorer i vid udstrækning bekræfter vores teoretiske model (figur 1). Bortset fra kilde 3 - 'studenterevalueringer', som indgår i både faktor 1 og faktor 2, afspejler de tre faktorer vores teoretiske indplacering af videnskilderne. Nedenfor gennemgås de tre faktorer hver for sig.

Hver faktor består af et antal videnskilder (som anført i figur 1) samt et antal spørgsmål, der refererer til studieledernes oplevelse af deres organisatoriske forhold.

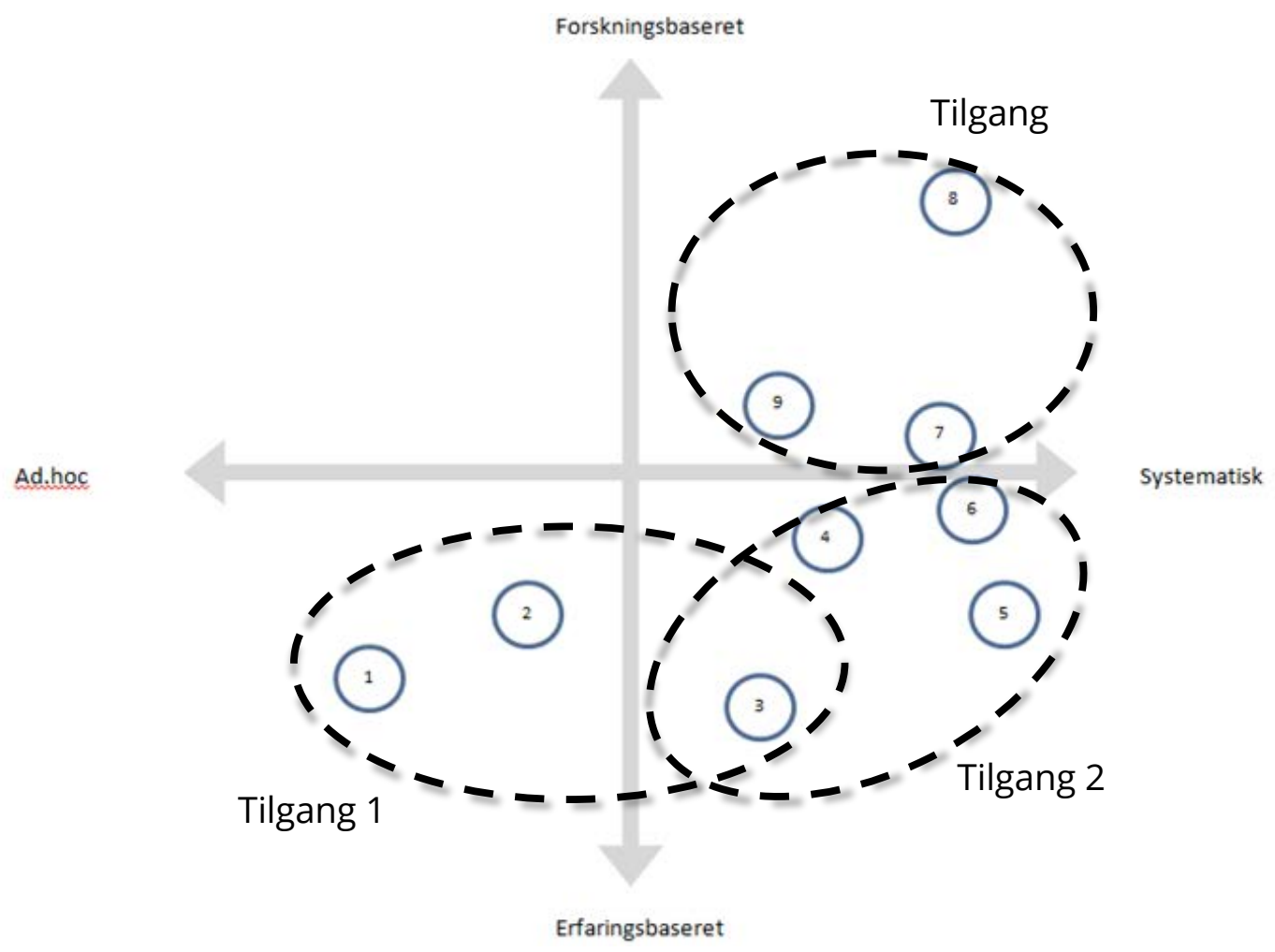

Figur 3. Tre tilgange til brug af viden

Tilgang 1: Traditionel kollegial studieledelse

De studieledere, der i høj grad bruger uformel eller anekdotisk viden, scorer samtidigt højt på følgende to udsagn om deres organisatoriske forhold: 'Det er vigtigt for mig at undervise eller vejlede studerende for at have føling med de studerende' og 'jeg opfatter studienævnenes arbejde som et vigtigt demokratisk element i universitetets ledelsesstruktur'.

Vores tolkning af denne tilgang til studieledelse er kendetegnet ved, at man prioriterer samtaler med den lokale organisation, og ser kontakten med studerende og kolleger 
som vigtig. Vi vurderer, at denne tilgang ligner den, der er beskrevet af bl.a. Dopson og McNay (1996), som beskriver traditionelle, kollegiale faglige ledere, hvor ledelse er baseret på ideen om en 'organization of consent', hvor medarbejderne forventer at blive inddraget i beslutninger, hvor beslutningsprocesser er udpræget bottom-up, og hvor lederne følgelig har en præference for at praktisere ledelse gennem 'management by walking about, sensing views and generating consensus and compromise'.

\section{Tilgang 2: Bureaukratisk studieledelse}

De studieledere, der ifølge dem selv i høj grad bruger administrative data, scorer samtidigt højt på udsagnet: 'Jeg vurderer, at studieledelsesarbejdet kan være godt for min karriere fremover'. Samtidigt scorer de lavtpå udsagnet: 'Det er tydeligt for mig, at der er stor forskel på hvordan studieledelse på KU er organiseret'.

Vores tolkning er, at dette er studieledelse i den bureaukratiske organisation. Bemærk, at ordet bureaukrati her skal opfattes som en neutral deskriptor. Der er både fordele og ulemper ved bureaukratiet. Som Birnbaum (1988) anfører: "The word bureaucracy is so burdened by connotations of rigidity, waste, and lack of human concern that merely mentioning it in the context of [university] life almost always provokes responses ranging from helpless shrugs to cries of outrage [...] [We] will consider 'bureaucracy' to refer to 'the type of organization designed to accomplish largescale administrative tasks by systematically coordinating the work of many individuals' (Blau, 1956). Bureaucratic structures are established to efficiently relate organizational programs to the achievement of specified goals. When behavior is standardized, the activities and processes of organizations are made more predictable, so the organization can become more efficient and effective".

Vores data angiver, at studielederne inden for denne tilgang dels er optaget af en ledelseskarriere, dels ikke mener at der er stor forskel på hvordan studieledelse på KU er organiseret. Sidstnævnte selvom der faktisk er stor forskel på hvordan studieledelse er organiseret på KU, jfr. tabel 1. Når studielederne trods dette ikke kan få øje på forskellene, kan det skyldes (mindst) to forhold: (1) De ser deres primære funktion som en lokal ledelsesfunktion i tilknytning til deres eget instituts/fakultets studieadministration, og har derfor kun begrænset kontakt med studieledere uden for eget institut/fakultet eller (2) de deltager i administrative opgaver både på og uden for eget fakultet (KUs centrale studieadministration), hvor de administrative procedurer netop er kendetegnet ved at være standardiserede og ens på tværs af fakulteter. Det er de mere fagligt ledelsesmæssige opgaver, der er forskellige, så som arbejdsopgaver ift. underviserne ('bemanding' af kurser, etc.). Samtidig indebærer tilgangen som nævnt, at studieledelse ses som et springbræt til en videre karriere - måske fordi man trives i det administrative system? Og måske fordi ledelsesfunktionen er mere tydelige/veldefineret her? 


\section{Tilgang 3: Scholarship of Educational Leadership (SoEL)}

De studieledere, der har en præference for forskningsbaseret viden, scorer samtidig højt på udsagnet: "Jeg oplever, at viden om pædagogiske forhold kvalificerer mit studieledelsesarbejde".

Vores tolkning er, at dette er en faglig funderet ledelsestilgang, hvorunder også læring og pædagogik indgår som en central del. I faglitteraturen tales der om 'Scholarship of Teaching and Learning' (SoTL) (Boyer, 1990; Hubball, Pearson \& Clarke 2013; Saroyan \& Trigwell 2015). Selve tanken bag scholar-tilgangen handler om at man tilgår sin undervisning med samme omhyggelighed, integritet, skepticisme, intellektuelle ydmyghed og ønske om blive klogere, som man tilgår sin forskning (scholarly). I naturlig forlængelse heraf er opstået 'Scholarship of Educational Leadership (SoEL)'. SoTL, og SoEL, handler ikke nødvendigvis om, at universitetsforskere generelt skal skrive fagfællebedømte artikler inden for universitetspædagogik, men det indebærer, at man bygger videre på eksisterende viden og måske vigtigst af alt, at man fremlægger sine tanker og resultater for sine fagfæller og diskuterer det med dem.

Det forhold at denne tilgang faktisk findes blandt studielederne i vores undersøgelse er i sig selv interessant, fordi det formentligt er nyt inden for studieledelse. Det bør også være en kilde til fornyede refleksioner over hvordan ledelsestræningen af studielederne skal konstrueres. Og medhensyn til dette viser vores statistiske analyse, at studieledere, der har deltaget i universitetets ledelsesudviklingsforløb for studieledere, oplever sig signifikant mindre isolerede og pressede end de, der ikke har deltaget i forløbet.

Samlet set peger vores faktoranalyse på, at studieledernes valg af forskellige typer kilder til løsning af daglige studieledelsesopgaver kan ses som en refleksion af deres foretrukne ledelsestilgang i specifikke problemsituationer. Ledelsestilgange og brug af videnskilder synes således at hænge sammen. Hvis der rykkes ved det ene, rykkes der ved det andet. Faktorerne er dog vel at mærke ledelsestilgange og ikke studieledertyper, så en studieleder kan godt være bureaukratisk leder i en situation og traditionel leder i en anden.

\section{Diskussion}

Umiddelbart synes der at være en indre logik i hver af de tre faktorer, som vi har behandlet i denne artikel. Det synes fx plausibelt, at studieledere, der vægter tæt dialog med studerende, også vægter at have undervisning samt studienævnsarbejde for at have "føling" med de studerende. Det er en 'Management By Walking About (MBWA)', hvor kommunikation og personlige relationer vægtes. Tilsvarende plausibelt er det $\mathrm{fx}$, at de studieledere, der er hjemmevante med administrative videnskilder, også er de studieledere, der bedst kan se sig selv i en ledelseskarriere. Vi kunne her finde de studieledere, der er på vej til at blive "ledere med stort L'. Samlet set synes de tre 
faktorer hver for sig således at være både identificerbare og underbygget af faglitteraturen.

Men spørgsmålet er, hvordan det indbyrdes forhold fungerer mellem de identificerede tre faktorer. Vi kan konstatere, at alle tre faktorer praktiseres side om side, ikke blot inden for samme organisation, men ovenikøbet af samme ledelsesfunktion (studieleder). Men er det et samspil uden gnidninger? Harboe (2015) argumenterer, at der er tale om konkurrerende ledelsestilgange:

"Der er lang vej fra de kollegiale studieledere, der dagligt løber spidsrod mellem studerende, undervisere/forskere, studienævn, institutleder, fakultetsledelse og studieadministration i et forsøg på at få de mange ender til at mødes til den form for stærke superstudieledere, som de seneste universitetsreformer lægger op til, hvor det handler om, at studielederne skal tænke langsigtet og i helheder, og hvor midlet til at nå dette er at gøre studieledelsen mere hierarkisk veldefineret og studielederne mere professionelle og strategisk tænkende. Normalt vil man også opfatte traditionel kollegial ledelsestilgang og NPM-inspireret virksomhedspræget ledelsestilgang som hinandens modsætninger, hvor forstnæunte er mere forhandlende og bottom-up af natur, og sidstnævnte er mere strategisk og top-down af natur. Det er svært at forestille sig kombinationer eller overlap mellem disse."(Harboe, 2015).

Hvis dette er tilfældet, hvad siger det så om studieledelse som ledelsesfunktion, at to - og muligvis tre, hvis man inkluderer 'Scholarship of Educational Leadership (SoEL)' potentielt modsatrettede ledelsestilgange praktiseres side om side og af samme studieledere?

Kallenbergs (2016) analyser af 'third space professionals' kan bringe os nærmere en forståelse af dette. Med afsæt i Hanssons (2001) 'interacting spheres model' (figur 4) argumenterer Kallenberg for studielederen som en ny 'third space professional', hvis opgave det er at navigere og koordinere kompetent mellem administratorzonen og underviserzonen på universitetet. Hvor administratorzonen primært er drevet af formelle strukturer med fokus på strategi, kontrol og administrative processer, er underviserzonen drevet af operationelle og mere uformelle processer knyttet til undervisning (og forskning) med fokus på kvalitet og autonomi. Begge zoner har deres mål, rationaler og interesser, som til tider kan være svære at forene ('the contested zone'). Studielederen er situeret helt centralt i dette spændingsfelt, hvor han/hun i kraft af sin viden om og indsigt i både administrative og pædagogiske forhold i organisationen, kan spille en unik rolle som den, der kan både samle og forandre. Information og viden er således helt afgørende for studieledere, som ifølge Kallenberg (2015, s. 21) udgør "... an important link in the information flow of large organizations". 


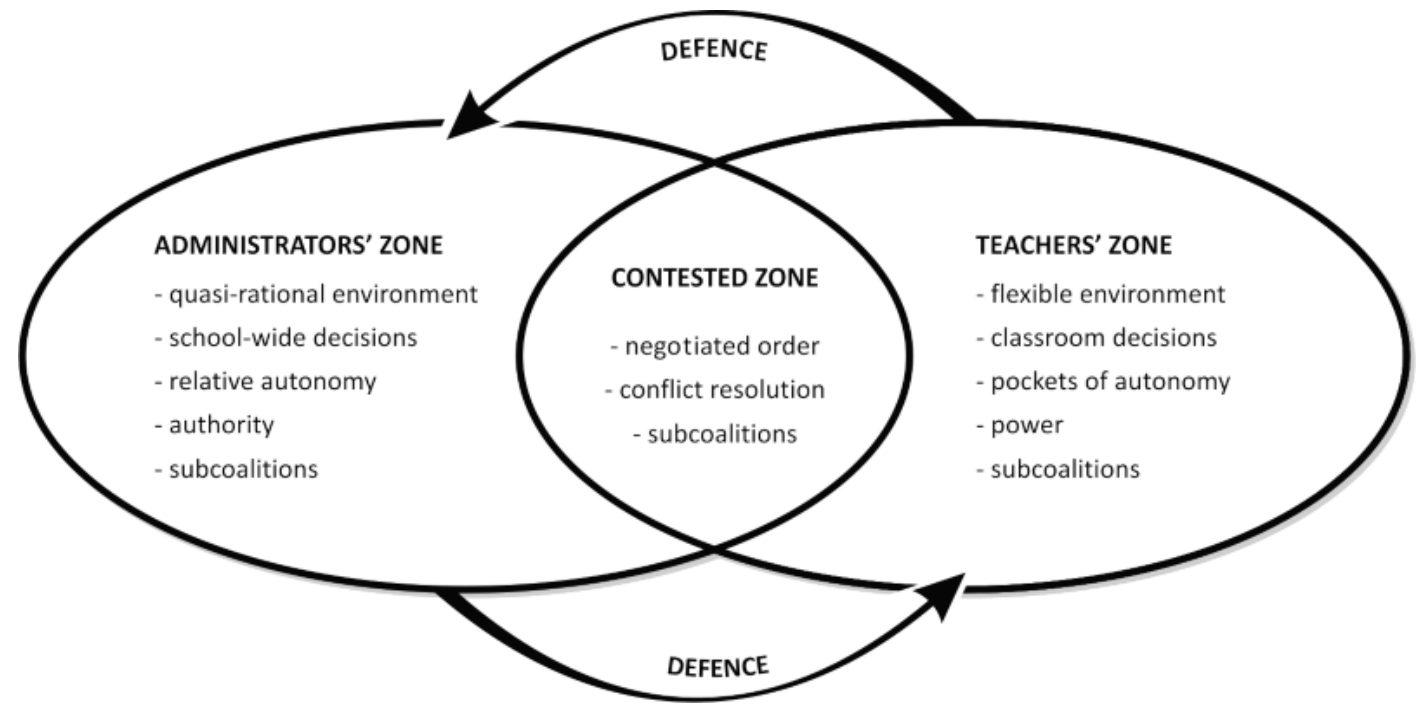

Figur 4. Interacting spheres model (Hansson, 2001)

Det er med andre ord en væsentlig del af studieledernes ledelsesfunktion at være 'gobetween'- ledere, dvs. at være ledere, der forbinder meget forskellige dele af samme organisation, både horisontalt og vertikalt. Konsekvensen er, at man som studieleder dagligt løber ind i problemkomplekser, der forudsætter en systematisk tilgang til viden samt færdigheder $\mathrm{i}$ at kunne omsætte denne viden til praksis - med andre ord: informationskompetence. Ofte kræves der brug af mange forskellige kilder. Nogle kilder er af kvantitativ art, hvor svaret ofte vil kunne findes i den ledelsesinformation, der oparbejdes i universiteternes administration, nogle svar kan findes i forskningslitteraturen, mens andre svar igen skal findes ved at tale med studerende, undervisere eller andre studieledere. Det kræver derfor meget forskelligartede tilgange at indhente den relevante eller nødvendige information og viden.

\section{Konklusion}

Denne undersøgelse af studielederes tilgang til viden og studieledelse bygger på en generel observation af, at studieledelse er i bevægelse ved danske universiteter. Ambitionen har været at opnå en større forståelse af, hvad der kendetegner studieledelse i dag, herunder hvorvidt vi kan sige noget om, hvordan nye forventninger til studieledernes ledelsesgrundlag (læs: brug af videnskilder) potentielt rykker ved studieledernes ledelsestilgange.

Vedrørende vores første forskningsspørgsmål finder vi, at studielederne bruger uformelle og anekdotiske videnskilder i signifikant højere grad $(p<0,05)$, end de bruger administrative eller forskningsbaserede kilder til viden om pædagogiske forhold (bredt forstået).

Vedrørende vores andet forskningsspørgsmål finder vi i vores faktoranalyse stærke indicier for, at ledelsestilgange er tæt linket til præferencer for videnskilder. Den måde 
studielederne henter deres viden om pædagogiske forhold kan med andre ord ses som en refleksion over hvordan studieledelse praktiseres, og omvendt.

Dette leder os frem til at identificere tre ledelsestilgange, der alle i forvejen findes i forskningslitteraturen: Traditionel kollegial studieledelse (og herunder 'Management By Walking About (MBWA)'), bureaukratisk studieledelse og 'Scholarship of Educational Leadership (SOEL)'.

I diskussionen sætter vi fokus på det indbyrdes forhold mellem de tre ledelsestilgange, og inddrager her teori om 'third space professionals'. Vores hypotese er her, at studieledernes placering $i$ 'the contested zone' mellem administration og pædagogik/forskning forklarer, hvorfor studielederne tilsyneladende praktiserer forskelligartede (og muligvis modsatrettede) ledelsestilgange side om side.

Relevansen af disse konklusioner finder vi bl.a. inden for ledelsestræning af studieledere. Især er koblingen mellem videnskilder og ledelsestilgange interessant, fordi viden om dette kan hjælpe med at fokusere ledelsestræningen mod et mål om også at udvikle informationskompetente studieledere. Informationskompetence bliver en nøglekompetence når man arbejder i 'the contested zone'.

\section{Metodekritik}

Vi vurderer, at både den interne og den eksterne validitet i denne undersøgelse er høj. Svarprocenten for spørgeskemaet er høj, hvilket i sig selv betyder, at vi har et solidt fundament. Samtidigt bekræfter faktoranalysen klart, at den teoretiske ramme (figur 1), der blev udviklet før faktoranalysens resultater, kan bruges til at beskrive forskellige ledelsesparadigmer inden for studieledelse. Sidst, men ikke mindst kan de identificerede ledelsestilgange i denne undersøgelse genfindes i forskningslitteraturen.

Undersøgelsen er imidlertid også præget af, at der er tale om et relativt lille datamateriale. Undersøgelsen er kun gennemført på et enkelt universitet, hvilket gør resultaterne sårbare for lokale bias. Samtidigt er enkelte spørgsmål i spørgeskemaet ikke helt så præcise, som vi kunne have ønsket, trods omhyggelige pilottest af både spørgeskema og analyseramme, hvilket udfordrer tolkningsarbejdet. En større og elaboreret undersøgelse vil kunne imødegå nogle af disse forbehold.

\section{Perspektivering}

Lad os afslutningsvist vende tilbage til anbefalingen fra Kvalitetsudvalget (2015) om, at der er behov for en langt mere systematisk og konsistent indsamling af ledelsesinformation på tværs af uddannelser og institutioner, hvis institutionsledelser, studieledelser, studerende, ministerier og politikere skal kunne arbejde målrettet med uddannelsernes kvalitet og relevans. Heri ligger flere ting. For det første en anbefaling af at både indsamle og bruge flere af de kilder til viden, vi har kaldt administrative data, og som kalder på bureaukratisk ledelse, og for det andet at kæde disse data sammen 
med spørgsmålene om kvalitet og relevans: Hvis der skal mere kvalitet og relevans i uddannelserne, skal der bruges flere administrative data.

Det er klart, at studieledere bør inddrage relevant viden i beslutninger vedrørende kvaliteten af vores uddannelser. Det er også klart, at den viden, studielederne får ved at 'lytte på vandrørene' og i kontakten til de studerende og underviserne er vigtig, men denne form for viden er omvendt ofte af anekdotisk karakter og kan derfor sjældent stå alene, når der skal tages beslutning i en sag. Set i dette lys er anbefalingerne om at sikre et mere systematisk og standardiseret ledelsesgrundlag fornuftige.

Men der er også et dybere og mere politisk perspektiv i dette, og det har at gøre med potentielle implikationer for, hvordan kvalitet i undervisningen opfattes, når man arbejder med hhv. den situerede og/eller den standardiserede og målbare tilgang. Når fx kvalitet i uddannelse kommer til at handle om sammenlignelighed og indikatorer mere end om studerendes oplevelser af læring eller undervisernes vurdering af undervisning - drejes studieledelsens fokus naturligt mod bureaukratiske ledelsestilgange, såsom styring, kontrol og målbare resultater.

Vi tænker på denne baggrund, at en større undersøgelse af informationskompetente studieledere med fordel kan inkludere spørgsmål om, hvordan de forskellige ledelsestilgange opfatter kvalitet, herunder om en bevægelse mod mere systematisk og standardiseret ledelsesgrundlag potentielt også rykker kvalitetsbegrebet væk fra et lokalt og praksisnært kvalitetsbegreb og mod et mere generaliseret og policy-drevet kvalitetsbegreb. Foreløbigt er dette dog blot en hypotese.

\section{Thomas Harboe er til dagligt leder af Pædagogisk Center Samfundsvidenskab og er som sådan bredt involveret i det universitetspædagogisk arbejde. Han har skrevet en ph.d. om studieledelse ved danske universiteter og har fokuseret fagligt på dette område siden. I dag er han også projektleder for KU's universitetspædagogiske ind- sats rettet mod studieledelse på hele $K U$.}

Camilla Østerberg Rump arbejder til dagligt som lektor ved Institut for Naturfagenes Didaktik og er som sådan bredt involveret i det universitetspædagogisk arbejde. Hun har de seneste tre år været involveret i KU's ledelsesprogram rettet mod studieledere.

Jette Seiden Hyldegård arbejder til dagligt som studieleder ved Det Informationsvidenskabelige Akademi. Hun har de seneste to år været involveret i KU's ledelsesprogram rettet mod studieledere.

Jesper Bruun arbejder til dagligt som adjunkt ved Institut for Naturfagenes Didaktik og har her særligt arbejde med kvantitative metoder. 


\section{Litteratur}

Boyer, E. L. (1990). Scholarship revisited: Priorities in the professoriate. Princeton, NJ: Carnegie Foundation for the Advancement of Teaching.

Birnbaum, R. (1988). How Colleges Work. The Cybernetics of Academic Organization and Leadership. San Francisco: Jossey-Bass.

Christiansen, N. F. V.; Harboe, T.; Horst, S., Krogh, L. \& Sarauw, L. L. (2013).

Udviklingstenderser i universitetets rolle. I Rienecker, L.; Jørgensen, P. S.; Dolin, J. \& Ingerslev, G.H. (red.): Universitetspædagogik (pp. 15-41). Frederiksberg: Samfundslitteratur.

Dopson, S. \& McNay, I. (1996). Organizational Culture. I D. Warner og D. Payfreyman (red.): Higher Educational Management - The Key Elements (pp. 16-32).

Buckingham: Open University Press.

Hanson, E. M. (2001). Educational administration and organizational behaviour (4th ed.). Boston, MA: Allyn and Bacon.

Harboe, T. (2013). Subtil ledelse i en ny og mere insisterende form. Et kvalitativt studie af studieledere ved danske universiteter. Syddansk Universitet. (Ph.D.afhandling)

Harboe, T. (2015). Danske studieledere står ved en kritisk skillevej. Dansk Universitetspædagogisk Tidsskrift, Årg. 10, Nr. 19 (pp. 22-33).

Harboe, T.; Rump, C. Østerberg; Hyldegård, J \& Bruun, J. (2016). Tracing a hidden management reform within academic middle management?The Association for the Study of Higher Education (ASHE), 41st Annual ASHE Conference, November 9-12 2016. Ohio, USA. (conference paper)

Hubball, H. \& Edwards-Henry, A. (2011). International collaboration to align institutional teaching development, learning-centred curricula, and the scholarship of curriculum and pedagogy in higher education. Caribbean Teaching Scholar, 1(1), 35-47.

Hubball, H.; Pearson M. L. \& Clarke, A. (2013). SoTL Inquiry in Broader Curricular and Institutional Contexts: Theoretical Underpinnings and Emerging Trends.

Teaching \& Learning Inquiry: The ISSOTL Journal, 1(1), 41-57.

Jensen, H.T.; Lehmann, H.; Pedersen, K.; Gravesen, E.; Hansen, B.; Østrup, K. (2009). Universitetsledelse. Frederiksberg. Handelshøjskolens forlag.

Kallenberg, T. (2007). Strategic innovation in HE: The roles of academic middle managers. Tertiary Education Management, 13(1), 19-33.

Kallenberg, A.J. (2015). Academic Middle Managers shaping the landscape between policy and practice (pp. 201-216). I Pritchard R.; Klumpp, M., \& Teichler, U. (red.): Diversity and Excellence in Higher Education: Can the Challenges be Reconciled? Rotterdam: Sense Publishers.

Kallenberg, T. (2016). Interacting spheres revisited - academics and administrators between dualism and cooperation. I: Pritchard, R.M.O.; Pausits, A., \& Williams, J. 
(red.): Positioning Higher Education Institutions: From here to there. Rotterdam: Sense Publishers.

Kristensen, J. E.; Nørreklit H., \& Raffnsøe-Møller, M. (2011). University performance Management - A Silent Managerial Revolution of Danish Universities. København: DJøF Publishing.

Mårtensson, K.; Roxå, T. \& Stensaker, B. (2014). From quality assurance to quality practices: an investigation of strong microcultures in teaching and learning. Studies in Higher Education, 39(4), 534-545. DOI:

10.1080/03075079.2012.709493.

Mårtensson, K. \& Roxå, T. (2016). Leadership at a local level - enhancing educational development. Educational Management Administration \& Leadership, 44(2), 247-262.

Rigsrevisionen (2008): Beretning til Statsrevisorerne om sikring og udvikling af kvaliteten af universitetsuddannelserne. Hentet fra: http://www.rigsrevisionen.dk/media/1838693/11-2007.pdf.

Saroyan, A. \& Trigwell, K. (2015). Higher education teachers' professional learning: Process and outcome. Studies in Educational Evaluation 46, 92-101.

SCONUL - Society of College, national and Universiy Libraries, working group on information literacy (2011). The seven pillars of information literacy - core model for higher education. (accessed 19-02 2017)

Udvalg for Kvalitet og Relevans i de Videregående Uddannelser (2015). Nye veje og høje mål. Kvalitetsudvalgets samlede forslag til reform af de videregående uddanne/ser. Hentet fra: http://ufm.dk/publikationer/2015/nye-veje-og-hojemal/nye-veje-og-hoje-mal-kvalitetsudvalgets-samlede-forslag-til-reform-af-devideregaende-uddannelser.pdf.

Wright, S. \& Ørberg, J.W. (2008). Autonomy and control: Danish university reform in the context of modern governance. Learning and Teaching. 